\title{
Opinions of Students and Teachers in Primary School Towards Online Learning During COVID-19 Outbreak
}

\author{
Chananya Wongjamnong $^{1}$, Chinathip Muangou ${ }^{2}$, Prasart Nuangchalerm ${ }^{3}$ \\ ${ }^{1}$ Faculty of Education, Mahasarakham University, Thailand \\ * e-mail: prasart.n@msu.ac.th
}

\begin{abstract}
This research aimed to study the opinions of students and teachers in primary school towards online learning during the COVID-19 outbreak. The informants were 106 students and 45 teachers from one primary school, Mahasarakham province, Thailand, in Semester 2 Academic Year 2020. Questionnaires were used for data collection through Google form. Percentage, mean, and standard deviation were employed for data analysis. Findings showed that students had opinions towards online learning during the COVID-19 outbreak were at a high level. However, teachers are the quite fluctuating level of their opinion between high and low levels. The discussion represents that students are ready to have online learning than teachers who are not familiar with the technology. Teachers need to reskill or upskill in the field of educational technology within and post-outbreak.
\end{abstract}

Keywords: COVID-19, online learning, instruction, new normal life

\section{INTRODUCTION}

In the uncertain situation of the COVID19 pandemic, school is a very high-risk place for spreading of virus due to it consists of a large group of people (Cruwys et al., 2020; Gaffney, A. W., Himmelstein, D., \& Woolhandler, 2020; Rundle, A. G., Park, Y., Herbstman, J. B., Kinsey, E. W., \& Wang, 2020). There is a risk of spreading the virus easily if it is poorly managed in school environment (Esposito, S., \& Principi, 2020). The educational policy in Thailand establishes safe for all by launch distance education or online learning in the situation of COVID-19 outbreak. If there is a continuous and heavier epidemic, there will be organize online instruction as well as other countries. Also, if the epidemic situation unravels, it will be able to arrange the school's teaching as usual. There can be many forms of teaching: traditional learning mixed with online learning. COVID-19 outbreak effected on teaching in broader school management. As a result, schools have had to resolve the issue by temporarily closing schools during the outbreak to prevent harm to students and teachers within the school (Jandrić, P., Hayes, D., Truelove, I., Levinson, P., Mayo, P., Ryberg, T., Monzó, L.D., Allen, Q., Stewart, P. A., Carr, P. R., Jackson, L., Bridges, S., Escaño, C., Grauslund, D., Mañero, J., Lukoko, H. O., Bryant, P., Fuentes-Martinez, A., Gibbons, A. St, 2020; Sleiwah, A., Mughal, M., Hachach-Haram, N., 2020). Some schools have stopped teaching for a long period of time, but discussions are needed to find suitable ways for students to have their teaching (Bryson \& Andres, 2020). Because the student's long-term stop will have a longterm impact on the student's learning and experience in the future (Munro, A. P., \& Faust, 2020). It is necessary to adjust the teaching style in a new way that can be used at home in each condition of the student's availability. That is, instruction during the outbreak of COVID-19 teachers need to have a 
management plan to learn to make them more learning.

From the outbreak, school is a risk area for spreading and harm to all students. But, students can't learn on their own at any time or stop learn in entire period. Parents need to be closely monitored their learning progress. Online learning is an alternative schooling or smart classroom in the new normal education (Dhawan, 2020; Sun, L., Tang, Y., \& Zuo, 2020). Students have to learn from home and teachers have to prepare and design the lesson through online environments. Learning make them unhappily and anxiety with complex lesson, less interaction between teacher and students. This affects the activities of teaching activities, a changing approach requires teachers and students to learn and adapt at the same time in order to provide guidance on teaching activities (Smoyer et al., 2020).

However, students do not have the readiness of online learning technology. Therefore, the teacher must solve the problem by having students pick up their worksheets to self-study and learn at home, and then send home works to the teacher in next time. In this study, the researchers wanted to study the opinions of students and teachers toward online learning during COVID-19 outbreak. One primary school in Mahasarakham province is case study to report of how they think. Result is a way of managing learning to educate learners and that can be applied in educational management.

\section{METHODS}

\section{Participant}

The survey method is employed by focusing on the students and teacher opinions and discussion towards online teaching during. Participants were 106 students and 45 teachers in one primary school, Mahasarakham province, Thailand. Data were obtained from participants in the second semester, academic year 2020. They have willingness to participate in January 2021.

\section{Research Tool}

The research tools are questionnaires of students and teachers toward online learning during COVID-19 outbreak. Each questionnaire consisted of 20 items, which are scaled by 4-level (4-very high; 3-high; 2-low; 1 -very low). The researchers conducted additional interviews with a semi-structured interview to be used as supporting information from the above feedback inquiries.

\section{Data Collection and Analysis}

The researchers collected the data by handing out questionnaires. The researchers examined the accuracy and integrity of the data, then analyzed the data using basic statistics such as frequency, percentage, mean, and standard deviation. The average score earned against the opinion level is as follows:

Mean score of 3.51-4.00 means very high level

Mean score of 2.51-3.50 means high level Mean score of 1.51-2.50 means low level Mean score of 1.00-1.50 means very low level

The data from the analysis is used to group the issues and present them in essays to explain the students and teachers' opinion towards online instruction during the COVID19 outbreak.

\section{FINDING AND DISCUSSIONS}

\section{Opinion of Students Towards Online Learning During COVID-19 Outbreak}

The opinions of student towards online learning found that they had high level. The most items were at high level by arrangement in 3 top items can be listed: I can communicate freely with my friends through online, I can communicate with my friends same as studying at school, and teachers can provide good advice on online learning. More details of each items can be shown in Table 1 .

Table 1. Students' opinions on online learning

\begin{tabular}{|c|c|c|c|}
\hline Item & Mean & SD & $\begin{array}{l}\text { Level of } \\
\text { opinion }\end{array}$ \\
\hline $\begin{array}{l}\text { I think that despite being } \\
\text { studying at home, I do } \\
\text { group activities like a } \\
\text { normal classroom }\end{array}$ & 2.57 & 0.78 & High \\
\hline
\end{tabular}




\begin{tabular}{|c|c|c|c|}
\hline Item & Mean & SD & $\begin{array}{l}\text { Level of } \\
\text { opinion }\end{array}$ \\
\hline $\begin{array}{l}\text { I feel that each activity } \\
\text { takes close to a normal } \\
\text { class }\end{array}$ & 2.50 & 0.80 & Low \\
\hline $\begin{array}{l}\text { I feel free to express my } \\
\text { opinion through online } \\
\text { learning }\end{array}$ & 2.91 & 0.77 & High \\
\hline $\begin{array}{l}\text { I participate in online } \\
\text { classes such as Q\&A, } \\
\text { discussion, suggestions, } \\
\text { timely submissions }\end{array}$ & 2.60 & 0.76 & High \\
\hline $\begin{array}{l}\text { I have less stress than } \\
\text { studying at school }\end{array}$ & 2.84 & 1.00 & High \\
\hline $\begin{array}{l}\text { I can learn lessons on my } \\
\text { own }\end{array}$ & 2.38 & 0.81 & High \\
\hline $\begin{array}{l}\text { I can make my own } \\
\text { home work }\end{array}$ & 2.70 & 0.80 & High \\
\hline $\begin{array}{l}\text { I can communicate freely } \\
\text { with my friends through } \\
\text { online }\end{array}$ & 3.34 & 0.77 & High \\
\hline $\begin{array}{l}\text { I can learn something } \\
\text { new based on my } \\
\text { interests more than at } \\
\text { school }\end{array}$ & 2.99 & 0.85 & High \\
\hline $\begin{array}{l}\text { I can work and send } \\
\text { worksheet to teachers via } \\
\text { online }\end{array}$ & 2.74 & 0.86 & High \\
\hline $\begin{array}{l}\text { I can communicate with } \\
\text { my friends same as } \\
\text { studying at school }\end{array}$ & 3.11 & 0.82 & High \\
\hline $\begin{array}{l}\text { I can regularly contact } \\
\text { and consult with teachers }\end{array}$ & 2.83 & 0.85 & High \\
\hline $\begin{array}{l}\text { Teacher takes good care } \\
\text { of my lesson }\end{array}$ & 2.95 & 0.72 & High \\
\hline $\begin{array}{l}\text { Teachers can provide } \\
\text { good advice on online } \\
\text { learning }\end{array}$ & 3.00 & 0.71 & High \\
\hline $\begin{array}{l}\text { Teachers can organize } \\
\text { teaching activities online }\end{array}$ & 2.96 & 0.82 & High \\
\hline $\begin{array}{l}\text { I have the availability of } \\
\text { online } \\
\text { equipment }\end{array}$ & 2.88 & 0.80 & High \\
\hline $\begin{array}{l}\text { I have an intention to } \\
\text { teach online }\end{array}$ & 2.64 & 0.81 & High \\
\hline $\begin{array}{l}\text { I love learning at a wide } \\
\text { variety of online media }\end{array}$ & 2.75 & 0.79 & High \\
\hline $\begin{array}{l}\text { I developed my online } \\
\text { learning skills }\end{array}$ & 2.61 & 0.75 & High \\
\hline $\begin{array}{l}\text { I have developed my } \\
\text { communication skills in } \\
\text { a new way }\end{array}$ & 2.89 & 0.76 & High \\
\hline
\end{tabular}

Students had high level of opinion towards online learning, but they feel uncommon with online learning by showing in item I feel that each activity takes close to a normal class. They were unable to learn in class as usual, psychological factors in new normal classroom may be affected (Angelova,
2020; Wijaya, 2020). The classroom atmosphere is missing that is, students worry most about: the continuation of learning content to be received. Self-learning at home may not be effective enough when compared to traditional classroom. It does not respond to teachers candidly in respect of content that they suspect or do not understand. Lack of interaction between groups of friends. In addition, it was found that the learner was unable to allocate and divide the time to learn on their own at home appropriately. Most of the time it takes to play games, listen to music, and mainly watch TV. Few students are ready to revisit the prior knowledge that teachers have taught.

Advantage of studying through online at home is that students no need to wake up early to school. Students are freely participated to learn, to access content which they are interested in (Dhawan, 2020). Learning is more flexible because regular classroom instruction is quite limited and not too crowded. Students are quite tired and stressed by traditional classes. They can learn anywhere, anytime, and can review lesson (Ilyas, 2020). However, they may be some contents that students do not understand. Teachers cannot be questioned at the moment, lack of counselors in exchange for mutual learning, teacher care may not be thorough. Some students who are not yet ready to study online may be deprived of the opportunity to learn.

\section{Opinion of Teachers Towards Online Learning During COVID-19 Outbreak}

The opinions of teacher towards online learning found that they had a fluctuating opinion between high and low levels. The most items were at high level by arrangement in 3 top items can be listed: I can learn to design lessons by myself, I am intent on teaching online, and I can assign a work sheet to a student via online. More details of each items can be shown in Table 2 .

Table 2. Teachers' opinions on online teaching

\begin{tabular}{l|c|c|c}
\hline \multicolumn{1}{c|}{ Item } & Mean & SD & $\begin{array}{c}\text { Level of } \\
\text { opinion }\end{array}$ \\
\hline I love online teaching & 2.33 & 0.67 & Low \\
\hline $\begin{array}{l}\text { I can engage students in } \\
\text { online teaching }\end{array}$ & 2.56 & 0.65 & High \\
\hline I can organize active & 2.47 & 0.69 & Low \\
\hline
\end{tabular}




\begin{tabular}{|c|c|c|c|}
\hline learning activities online & & & \\
\hline $\begin{array}{l}\text { I felt there was more } \\
\text { opportunity to make my } \\
\text { own decisions than } \\
\text { regular teaching }\end{array}$ & 2.38 & 0.57 & Low \\
\hline $\begin{array}{l}\text { I have less stress than } \\
\text { regular teaching }\end{array}$ & 2.67 & 0.84 & High \\
\hline $\begin{array}{l}\text { I can learn to design } \\
\text { lessons by myself }\end{array}$ & 3.00 & 0.61 & High \\
\hline $\begin{array}{l}\text { I can assign a work sheet } \\
\text { to a student via online }\end{array}$ & 2.87 & 0.72 & High \\
\hline $\begin{array}{l}\text { I can communicate freely } \\
\text { with students via online }\end{array}$ & 2.71 & 0.69 & High \\
\hline $\begin{array}{l}\text { I was able to learn } \\
\text { something new based on } \\
\text { my interests }\end{array}$ & 2.84 & 0.60 & High \\
\hline $\begin{array}{l}\text { I can assign students } \\
\text { online }\end{array}$ & 2.73 & 0.68 & High \\
\hline $\begin{array}{l}\text { I can communicate with } \\
\text { students in such at school }\end{array}$ & 2.49 & 0.69 & Low \\
\hline $\begin{array}{l}\text { Students can regularly } \\
\text { contact and consult with } \\
\text { teachers }\end{array}$ & 2.71 & 0.75 & High \\
\hline $\begin{array}{l}\text { Teachers can take good } \\
\text { care of their students' } \\
\text { learning }\end{array}$ & 2.47 & 0.65 & Low \\
\hline $\begin{array}{l}\text { Teachers give you good } \\
\text { online learning advice }\end{array}$ & 2.47 & 0.72 & Low \\
\hline $\begin{array}{l}\text { Teachers can organize } \\
\text { teaching activities online }\end{array}$ & 2.49 & 0.69 & Low \\
\hline $\begin{array}{l}\text { I have the readiness of } \\
\text { online } \\
\text { equipment }\end{array}$ & 2.67 & 0.67 & High \\
\hline $\begin{array}{l}\text { I am intent on teaching } \\
\text { online }\end{array}$ & 2.91 & 0.69 & High \\
\hline $\begin{array}{l}\text { I have great control over } \\
\text { the time of online } \\
\text { teaching activities }\end{array}$ & 2.60 & 0.65 & High \\
\hline $\begin{array}{l}\text { I developed my online } \\
\text { teaching skills }\end{array}$ & 2.76 & 0.60 & High \\
\hline $\begin{array}{l}\text { I have developed a new } \\
\text { form of communication } \\
\text { skills }\end{array}$ & 2.82 & 0.64 & High \\
\hline
\end{tabular}

The low level of their opinion towards online learning can be listed in 7 items: I love online teaching, I felt there was more opportunity to make my own decisions than regular teaching, I can organize active learning activities online, teachers can take good care of their students' learning, teachers give you good online learning advice, I can communicate with students in such at school, and teachers can organize teaching activities online as it in the following. These are stress about online instructional practices because unfamiliarity with new normal of learning environment.
The interview can support their opinions, online line may not suitable with teachers in the rapid change or disruptive education era. They need more time to reskill in educational technology and learn how to engage students in the lesson through multimedia. However, online learning may be suit for young students, response to nature of learning in the $21^{\text {st }}$ century students. The gap of teaching and learning through internet technology make teachers feel not comfortable, but their role and responsibilities are trying to grow intellectual and necessary learning skills to students. Adaptation in new normal environment, learning to live with world change, and shaping themselves towards online learning. The interviewing evidences can be shown.

"...online learning influence efficiency of teaching and learning, it is less ..." (Teacher A,18 January 2021)

"...the instructional practice is low, students have differences in learning quality. Student who has technology and family-aided learning is ready to learn by his/her ability..." (Teacher B,18 January 2021)

“...it makes students have less

interesting, no classroom control, then make long term in low learning achievement..." (Teacher C,19 January 2021)

Teachers have commented on the limitations of online learning in the pandemic era, students lack the availability of equipment, learn by themselves at home and away from school. However, it can reduce travel costs for students who are far from school, students can learn in what and how interesting by anytime anywhere. The competency of teachers to design a lesson and manipulate classroom by using internet and communication technology should be continuously developed (Akarawang et al., 2015, Akrawang, 2016). Technology in education is now rapidly changed and influence to learning environments. Students can access new knowledge by various kinds of methods and tools for learning (P. Nuangchalerm, 2017; Prasart Nuangchalerm, 2020). That is the reason why and how teachers reskill and upskill about educational technology. 
The concept of integration technology into classroom is not new, but teachers should employ TPACK or technological pedagogical content knowledge into classroom in modern schooling. The understanding about online learning and also technology in pedagogical strategies are promoted by TPACK approaches (Fuad et al., 2020; Kholik et al., 2020; P. Nuangchalerm, 2017). Teachers are ready to design online instruction as well as the world of technology is now growing and continuing to the future (Korkmaz \& Toraman, 2020). Even though COVID-19 break the social, economical, and educational activities students cannot stop learning because they are facing with uncertainty. The process of education should be run in the appropriate way by using technology as a tool for learning together. The study is narrow school, but it can reflect to the context of learning during pandemic.

\section{CONCLUSION}

Students had opinions towards online learning during COVID-19 outbreak were at high level. They are ready to participate new normal classroom by using technology due to nature of learning and learning environments emerge in their generation. Teachers are quite fluctuating level of their opinion between high and low levels. They are quite not ready with online instructional practices, familiar with traditional classroom than multimedia or active online learning. Equity in education is raised for the technology-enhanced and technologysupported classroom. Teachers need to reskill or upskill in field of educational technology within and post outbreak.

\section{REFERENCES}

Akarawang, C., Kidrakran, P., \& Nuangchalerm, P. (2015). Enhancing ICT Competency for Teachers in the Thailand Basic Education System. International Education Studies, 8(6), 1-8. https://doi.org/10.5539/ies.v8n6p1

Akarawang, C., Kidrakran, P., \& Nungchalerm, P. (2016). Developing ICT Competency for Thai Teachers through
Blended Training. Journal of Education and Learning (EduLearn), 10(1), 15-21. https://doi.org/10.11591/edulearn.v10i1.2 830

Angelova, M. (2020). Students' Attitudes to the Online University Course of Management in the Context of COVID-1. International Journal of Technology in Education and Science, 4(4). http://journal.uad.ac.id/index.php/EduLea rn/article/view/2830/pdf_111

Bryson, J. R., \& Andres, L. (2020). Covid-19 and Rapid Adoption and Improvisation of Online Teaching: Curating Resources for Extensive Versus Intensive Online Learning Experiences. Journal of Geography in Higher Education, 44(4), 608-623.

https://doi.org/10.1080/03098265.2020.18 07478

Cruwys, T., Stevens, M., \& Greenaway, K. H. (2020). A Social Identity Perspective on COVID-19: Health Risk is Affected by Shared Group Membership. British Journal of Social Psychology, 59(3), 584593. https://doi.org/10.1111/bjso.12391

Dhawan, S. (2020). Online Learning: A Panacea in the Time of COVID-19 Crisis. Journal of Educational Technology Systems, 49(1), 5-22. https://doi.org/10.1177/004723952093401 8

Esposito, S., \& Principi, N. (2020). Antibody Responses to SARS-CoV-2 in Patients with Novel Coronavirus Disease 2019. Clinical Infectious Diseases, 71(16), 2027-2034.

https://doi.org/10.1093/cid/ciaa344

Fuad, M., Ariyani, F., Suyanto, E., \& Shidiq, A. S. (2020). Exploring Teachers' tpck: Are Indonesian Language Teachers Ready for Online Learning During the Covid-19 Outbreak? Universal Journal of Educational Research, 8(11B), 60916102.

https://doi.org/10.13189/ujer.2020.082245

Gaffney, A. W., Himmelstein, D., \& Woolhandler, S. (2020). Risk for Severe COVID-19 illness Among Teachers and Adults Living With School-aged Children. Annals of Internal Medicine, 173(9), 765-767. 
Ilyasa, F., Rahmayanti, H., Muzani, M., Ichsan, I. Z., \& Suhono, S. (2020). Environmental Education for Prevent Disaster: A Survey of Students Knowledge in Beginning New Normal of COVID-19. International Journal on Advanced Science, Education, and Religion, 3(2), 1-8. https://doi.org/10.33648/ijoaser.v3i2.60

Jandrić, P., Hayes, D., Truelove, I., Levinson, P., Mayo, P., Ryberg, T., Monzó, L.D., Allen, Q., Stewart, P. A., Carr, P. R., Jackson, L., Bridges, S., Escaño, C., Grauslund, D., Mañero, J., Lukoko, H. O., Bryant, P., Fuentes-Martinez, A., Gibbons, A. St, S. (2020). No Title. Postdigital Science and Education, 2(3), 1069-1230. https://minervaaccess.unimelb.edu.au/handle/11343/2542 56

Kholik, A., Yektyastuti, R., Mawardini, A., Hamamy, F., Halim, D., Ramdhani, M. R., \& Gunadi, G. (2020). Analysis of Technological Pedagogical Content Knowledge ( Tpack ) on Indonesian Certified Teacher. PalArch's Journal of Archaeology of Egypt/Egyptology, 17(6), 8634-8642.

http://www.palarch.nl/index.php/jae/articl e/download/2269/2237

Korkmaz, G., \& Toraman, Ç. (2020). Are We Ready for the Post-COVID-19 Educational Practice? An Investigation into What Educators Think as to Online Learning. International Journal of Technology in Education and Science, 4(4), 293-309. https://doi.org/10.46328/ijtes.v4i4.110

Munro, A. P., \& Faust, S. N. (2020). Children are not COVID-19 Super spreaders: Time to go Back to School. Archives of Disease in Childhood, 105(7). https://pubmed.ncbi.nlm.nih.gov/3237144 2/

Nuangchalerm, P. (2017). International Journal of Advanced and Applied Sciences.
International Journal of Advanced and Applied Sciences, 4(7), 124-128. https://doi.org/https://doi.org/10.21833/ija as.2017.07.018

Nuangchalerm, Prasart. (2020). Tpack in Asean Perspectives: Case Study on Thai Pre-service Teacher. International Journal of Evaluation and Research in Education, 9(4), 993-999. https://doi.org/10.11591/ijere.v9i4.20700

Rundle, A. G., Park, Y., Herbstman, J. B., Kinsey, E. W., \& Wang, Y. C. (2020). COVID $\square$ 19-Related School Closings and Risk of Weight Gain Among Children. Obesity, 28(6), 1008-1009. Obesity, 28(6), 1008-1009.

Sleiwah, A., Mughal, M., Hachach-Haram, N., \& R. (2020). COVID-19 Lockdown Learning: he uprising of Virtual Teaching. Journal of Plastic, Reconstructive \& Aesthetic Surgery, 73(8), 1575-1592. Journal of Plastic, Reconstructive \& Aesthetic Surgery

Smoyer, A. B., O'Brien, K., \& RodriguezKeyes, E. (2020). Lessons learned from COVID-19: Being known in online social work classrooms. International Social Work, 63(5), 651-654. https://doi.org/10.1177/002087282094002 1

Sun, L., Tang, Y., \& Zuo, W. (2020). Coronavirus pushes education online. Nature Materials. Nature Materials, 19(6), 687-687.

Wijaya, T. T., Ying, Z., Purnama, A., \& Hermita, N. (2020). Indonesian students' learning attitude towards online learning during the coronavirus pandemic. Psychology, Evaluation, and Technology in Educational Research, 3(1), 17-25. https://doi.org/10.33292/petier.v3i1.56 